\title{
Topoisomerase I Inhibitor LMP400
}

National Cancer Institute

\section{Source}

National Cancer Institute. Topoisomerase I Inhibitor LMP400. NCI Thesaurus. Code C90594.

An indenoisoquinoline and non-camptothecin inhibitor of topoisomerase I (Top I) with potential antineoplastic activity. Topoisomerase I inhibitor LMP400 binds to the topoisomerase I-DNA covalent cleavage complexes, and inhibits repair of single-strand DNA breaks, DNA replication, and tumor cell growth in susceptible tumor cell populations. Compared to camptothecins, indenoisoquinolines are chemically stable, produce stable Top I-DNA cleavage complexes, induce unique DNA cleavage sites and appear more resistant to multidrug efflux pumps. 